\title{
Knowledge of People Diagnosed with Diabetes Mellitus about their Pathology
}

\author{
Renata da Silva Schulz ${ }^{1 *}$, Jéssica Ariadne Nascimento França², Larissa Teles Dias², Mônica \\ Valéria Pereira Machado², Tâmara Cristina Dias de Assis ${ }^{1}$, Darci de Oliveira Santa Rosa ${ }^{1}$ \\ ${ }^{1}$ Federal University of Bahia, Salvador, Bahia, Brazil \\ ${ }^{2}$ Jorge Amado University Centre. Salvador, Bahia, Brazil
}

*Corresponding Author: Renata da Silva Schulz, Federal University of Bahia, Salvador, Bahia, Brazil, Email: renata.s.schulz@gmail.com

\begin{abstract}
Aim: To determine the knowledge of people living with diabetes mellitus about their pathology.

Methods: A descriptive study with a quantitative approach was conducted at the Institute of Health, Jorge Amado University Centre in Salvador, Bahia, Brazil. Data collection was performed using a questionnaire applied by the researcher and research assistant. The study was conducted from September 2017 to May 2018. The study included 50 people, both adults and the elderly, who were receiving treatment for diabetes mellitus.
\end{abstract}

Results: Seventy-two percent of the study population comprised women; $60 \%$ were diagnosed during routine consultations; $46 \%$ had inadequate knowledge about the pathology; 52\% reported not knowing the difference between Type 1 and Type 2 diabetes; and $70 \%$ cited current ways of how to prevent foot injuries. The popular beliefs are still present in the investigated population which can affect the therapeutic conduct.

Conclusion: All the patients presented degrees of ignorance about their pathology; the use of medicinal plants was cited recurrently by participants. The patients had prior knowledge of the chronic complications, especially those related to lower limb amputations; however, despite knowing what care is essential for the feet, patients reported not wearing proper footwear. Health education is essential for the accumulation of knowledge in the self-care of diabetes mellitus.

Keywords: Diabetes mellitus; Knowledge; Self-care.

\section{INTRODUCTION}

In Brazil, the indicator of diabetes mellitus (DM) increases with age and is almost three times higher among those with lower schooling. In people aged between 18 and 24 years, for example, the rate is $0.9 \%$ per 100 thousand inhabitants; among people aged 35-44 years, the rate is 5.2\%, and among those aged 55-64 years, it reaches $19.6 \%$. [1] The largest number of cases, however, is in the population aged 65 years and older, which presents an index of $27.2 \%$. [1]

DM is a metabolic disorder evidenced by hyperglycaemia which may be associated with resistance in the action of insulin in the body and lack of production thereof. Its classification is based on the aetiology. Type 1DM is characterised by destruction of pancreatic beta cells resulting in deficiency of the hormone insulin, and Type $2 \mathrm{DM}$ is characterised by defects in the action and secretion of insulin in the body. [2] The diagnosis of DM is fundamentally based on changes in fasting plasma glucose ( 8 hours) or after an overload of glucose $(75 \mathrm{~g})$ orally. [3] There are diagnostic categories for both adults and for pregnant women, the latter called gestational diabetes. It is worth noting that if not treated appropriately, it can lead to acute and chronic complications. Among the acute complications, regardless of the type of DM, the most serious are hypoglycaemia, hyperosmolar hypoglycaemic state and diabetic ketoacidosis. [2]

Similarly, the chronic complications of DM are mainly due to inadequate control, time of evolution, and genetic factors of the disease. They are divided into microvascular and 
macrovascular complications. Micro vascular complications include nephropathy, retinopathy, and neuropathy. The macro vascular complications, as the name implies, are due to changes in the large blood vessels and cause acute myocardial infarction, stroke, and peripheral vascular disease. [4]

Diabetes has shown an increase in the Brazilian population. Data from the surveillance of risk factors and treatment of chronic diseases by telephonic survey in the country revealed that in 2015 , the frequency of prior medical diagnosis of diabetes was $6.5 \%$ per 100 thousand inhabitants, being $6.7 \%$ among men and $6.3 \%$ among women whose treatment was covered by health insurance. The Brazilian capital city with the highest prevalence of diabetes was Campo Grande, with $8.5 \%$ for every 100 thousand inhabitants. This was followed by the capitals of Maceió, Macapá and Rio de Janeiro (7.7\%, $7.3 \%$ and $7.0 \%$, respectively), São Paulo and Natal with $6.7 \%$ and Salvador, Rio Branco and Manaus with 6.6\%. [1]

Diabetes when controlled does not generate hospitalisation costs especially in relation to chronic complications. Data from the Unified Health System (SUS) show that in 2008 there were 121,168 hospitalisations with an annual cost of 53 million reais. In 2011, this figure exceeded 125 thousand hospitalisations, accounting for an increase in expenditure by 65 million reais. [5]

The ability of patients to understand their health situation and strategies for their treatment are the main ways to prevent complications. In this sense, the knowledge about the disease outcomes in health represents a way to aid the search for treatment when DM is already established. [6]

In Brazil, according to data from the National Health Survey, people who study less with and without chronic diseases had a higher prevalence of hospitalisation, stopped performing activities and did not follow medical monitoring for health. [7] Moreover, research data highlight that low educational level influences follow-up of the care plan. However, therapies in groups are cited as facilitators for understanding of the pathology and metabolic control which include exercise and nutritional education, among other therapies. [8]

In order for individuals to be able to manage chronic diseases such as diabetes, it is critical to impart skills to regularly monitor the symptoms of their conditions and to adapt their lifestyles. In this regard, the knowledge of its pathology and positive attitudes towards the disease assist in the process of adapting to the new reality; these attitudes can be taught and/or acquired. [9]

The knowledge of people living with diabetes mellitus about their pathology in this population is not completely known. Therefore, we aimed to determine the knowledge of people living with diabetes mellitus about their pathology.

\section{MeThodology}

This is a descriptive study with a quantitative approach conducted at the Institute of Health at Jorge Amado University Centre in Salvador, Bahia, Brazil. The Institute of Health is a clinicschool that provides multidisciplinary care in the promotion of health, involving nursing, physical education, physiotherapy, speech therapy, psychology, social work, and nutrition. It comprises 32 offices, 5 multidisciplinary laboratories, 3 physiotherapy gymnasiums, 1 pool for hydrotherapy, and an elevator for access by people with special needs.

The study consisted of 50 young adults and elderly participants. The inclusion criteria were: 18 years or older; having diabetes mellitus of any type diagnosed by a clinician at least 6 months prior. The exclusion criteria were: not having the mental capacity to discern the issues addressed; having complications secondary to diabetes mellitus.

The participants were selected through an analysis of the charts for outpatient care, at the time they attended the nursing visit, and were invited to participate in the study. For those who agreed to participate, free and full information about the study was presented before they signed the informed consent form. This agreement ensured the confidentiality of the information reported and the preservation of the participants' anonymity, as defined by Resolution 466 of December 12, 2012 [10]. The project was approved under the number: CAAE: 69471516.7.0000.0041 by the Ethics Committee of Estácio University and was conducted from September 2017 to May 2018.

It is worth mentioning that in order to maintain anonymity, participants were identified with the code "P" followed by a number according to the collection order (P1, P2, P3 ...). The collection of data occurred on days predetermined according to the appointment schedule. This was done using a form developed exclusively for this study, which was applied by the researcher and 
assistant to the participants in a reserved room, either immediately before or after the nursing consultation. The average duration of data collection was 30 minutes. The first part of the data collection form included demographic data, family income, schooling and duration since diabetes diagnosis. The second part was used to collect data concerning the knowledge of the disease such as: diabetes and its causes, foot care, and acute and chronic complications. Descriptive analysis of the data was performed and the results were tabulated according to the items surveyed in the form which were captured

Table1: Sociodemographic and clinical characteristics $(n=50)$. (Salvador, Bahia, 2017)

\begin{tabular}{|l|l|l|}
\hline \multicolumn{2}{|c|}{ Sociodemographic characteristics } & \\
\hline Sex & & \\
\hline Women & 36 & $72 \%$ \\
\hline Men & 14 & $28 \%$ \\
\hline Age & & \\
\hline $28-39$ years & 9 & $18 \%$ \\
\hline $40-59$ years & 15 & $30 \%$ \\
\hline $60-70$ years & 15 & $30 \%$ \\
\hline $71-81$ years & 11 & $22 \%$ \\
\hline Diabetes: years with diabetes & & \\
\hline $1-5$ years & 21 & $42 \%$ \\
\hline $6-10$ years & 9 & $18 \%$ \\
\hline $10-20$ years & 12 & $24 \%$ \\
\hline Longer than 20 years & 8 & $16 \%$ \\
\hline Family income & & \\
\hline $1-2$ family income & 37 & $74 \%$ \\
\hline 3-4 family income & 11 & $22 \%$ \\
\hline or more minimum salaries & 2 & $4 \%$ \\
\hline Educational level & & \\
\hline Illiterate & 4 & $8 \%$ \\
\hline Elementary or grade school incomplete & 4 & $8 \%$ \\
\hline Elementary or grade school & 11 & $22 \%$ \\
\hline High school incomplete & 7 & $14 \%$ \\
\hline High school & 22 & $44 \%$ \\
\hline Incomplete graduation & 2 & $4 \%$ \\
\hline
\end{tabular}

Higher numbers of women have been reported more frequently among the studies on diabetes. In addition, they have more interventions directed to the control of the pathology. [11] Similarly, we observed that in the clinical school where the research was performed, women were greater in number and the vast majority were elderly.

Regarding the diagnosis of DM, 60\% reported that they discovered the pathology during routine clinical visits; $28 \%$ when they experienced severe discomfort and were diagnosed after frequent tremors, sudden weight loss, signs of hypoglycaemia or hyperglycaemia; $6 \%$ during preoperative examinations; and the remaining $6 \%$ when they were pregnant. Routine consultations were and analysed using Microsoft Office Excel 2007. The results were presented as percentages.

\section{RESULTS AND DISCUSSION}

The sample consisted of 50 people of whom $72 \%$ were women. Participants were aged between 28 and 81 years and the mean age was 54.2 years. Forty-two percent had been diagnosed with diabetes for 1 to 5 years. With respect to family income, $74 \%$ of families had 1 to 2 members earning minimum wages, and $44 \%$ had completed high school (Table 1). paramount in the diagnosis of the condition, thus making prevention and health promotion of great assistance in this process. Thus, a good anamnesis favours the search for risk factors and the nurse should be attentive to co morbidities such as hypercholesterolemia, hypertriglyceridemia, arterial hypertension and cardiovascular diseases associated with diabetes. [12]

When requesting that people with diabetes define the pathology, 23 (46\%) described the knowledge about diabetes superficially, noting that only sugar would be related to their disease. Another 8 people (16\%) reported an improved perception of path physiology, mentioning terms such as metabolic disease, insufficient insulin production, and technical terms involving diabetes. 
Nevertheless, in relation to the knowledge of the pathology, it was observed that 8 people $(16 \%)$ demonstrated a limited view about the disease and they were sad to talk about the pathology, even though they did not have serious complications due to diabetes. Eleven people (22\%) did not know or did not want to comment. Of these, two of the participants had been with pathology for more than 20 years, with incomplete elementary education and four others with relatively short duration with the pathology (2 to 3 years), with complete secondary schooling who did not know or did not want to respond.

The lower level of education is considered a relevant factor for the low therapeutic adherence by patients with chronic diseases, making it difficult to control the pathology. ${ }^{8}$ In view of this, it is important that health education interventions aimed at this population be implemented in a simple and objective way, adapted to the sociocultural reality and respecting the specific limitations of the affected individuals. $[13,14]$ It is possible to make the person with diabetes responsible for the success of their therapy. For this, it is essential to instruct them to be concerned about their selfcare, using the health system as an aid in controlling their pathology. [15]

It was observed that a lack of knowledge was present and recurrent in the responses. Similarly, there was a misrepresentation involved with the pathology, as can be gauged from the sentences below:

\section{"It is hereditary and contagious" (P. 15)}

"It is too much sugar in the blood, it is a congenital disease" (P.30).

"Type 1 is when the patient has a wound and a Type 2patient does not" (P. 2)

The heredity role has been confirmed by findings in the literature [16]; however, the term "contagious" reveals their ignorance about its pathology or the term used as seen on P.15. Another example is the response on P.30 that referred to placental transmission incorrectly.

When asked about the diabetes classifications, 26 participants $(52 \%)$ reported not knowing the difference between Type 1 and Type 2, 5 (10\%) defined that Type 1 is more connected to children and Type 2 to adults correctly. Another $4(8 \%)$ demonstrated knowledge regarding the use of drugs in the different types of diabetes; 15 participants $(30 \%)$ reported diverse responses with no relation to the pathophysiology of the disease, as reported on P. 2.

The cure of diabetes was reported by two patients as follows: On P 34, it is stated that he believed that cure will be found in Brazilin, the cow's foot tea plant. This plant is known so due to the formation of its leaves. Its scientific name is Bauhinia forficata. Similarly, on P. 7, it is mentioned that the cure would be linked to intake of "bovine bile". Sixteen participants (32\%) did not respond, and the remaining 32 (64\%) expressed the knowledge that "diabetes has no cure but control".

The popular beliefs are still present in the imagination of the society, affecting the therapeutic conduct. Some species such Abelmoschus esculentus, Bauhinia forticata, Baccaris trimera, Quasia amara, Aloe vera, Morinda citrifolia, Hibiscus sabdariffa, and Citru limonium were mentioned by patients as coadjuvants to the treatment of DM. Based on these beliefs, studies have been conducted to identify whether the species used by the patients have a significant effect on the treatment [17]; however, to date there are no studies that prove the efficacy of these plants for glycaemia control. The research on plants with hypoglycaemic properties has been accentuated in recent years in order to increase the empirical knowledge, with a view to an improvement of the current therapeutics. The plants that currently present better prospects are Bauhinia forficata, Mormodica charantia, Eugenia jambolana, and Olea europaea [18].

It is imperative that natural products be evaluated scientifically, since the indiscriminate use associated with the drugs can potentiate its effect and cause serious health problems, such as severe hypoglycaemia. [19]

Regarding chronic complications, 13 participants $(26 \%)$ did not know or did not want to comment. However, the other 37 (74\%) showed some degree of knowledge about complications due to diabetes, as we can see in the following percentages: 28 indicated amputations; 16 indicated blindness; 12 indicated the use of haemodialysis or renal problems; 2 indicated sores on feet; 2 reported that hypertension and coronary problems were associated; 1 indicated neuropathy and 1 indicated death.

Of the acute complications, 17 (34\%) were unable to respond, 1 (2\%) reported hypoglycaemia, 1 (2\%) diabetic ketoacidosis, 4 
(8\%) hyperglycaemia, 2 (4\%) coma and 36 (72\%) patients confused the chronic complications with the acute complications of the disease.

When asked about multidisciplinary follow-up, 31 patients $(62 \%)$ answered that they were not followed up by a multidisciplinary team, 18 (36\%) reported that they were followed up by more than one professional; however, they did not mention which specialties. Only 1 patient (2\%) reported follow-up by a multidisciplinary team (nutrition, physiotherapy, nursing and medicine).

Regarding physical activity, 19 patients (38\%) did not know its importance, 31 patients $(62 \%)$ indicated some benefits of regular physical activity, such as speeding up metabolism, improving circulation, reducing cholesterol levels, controlling blood glucose levels and weight loss.

When questioned about foot care, 6 patients (12\%) interviewed did not know what care should be taken; 9 patients (18\%) knew what to do; however, they confirmed that they did not take special care of their feet. These data point to the need for health education. Thirty-five patients $(70 \%)$ reported that moisturising, avoiding very hot water, avoiding walking bare feet, drying well between the toes and wearing closed shoes were some of the care that should be taken; however, the patients did not report the use of appropriate shoes.

The literature proposes that footwear should have a square tip with a maximum height of 3 $\mathrm{cm}$ and should not have internal seams. The use of removable insoles is appropriate and it is advisable to wear shoes with socks only. In summer, it is advisable to wear slippers that are resistant and soft, and they should not have a strap between the toes. [20]. There are ways to identify and prevent complications of diabetic foot, such as the performance of neurological tests, such as the use of monofilaments, tactile stimuli, painful stimulus, vibratory thermal evaluation characterised by low cost, practicality and easy to use, ${ }^{2}$ In addition, clinical evaluation by means of anamnesis and physical examination with palpation of the pulse (posterior and dorsal tibial artery of the foot) and observation of foot care, such as evaluating mycoses, claw and hammer toes, and bone deformities, are measures adopted to avoid many of the complications such as the dreaded amputations. [21, 22]
It is extremely important that the professionals involved in the treatment consider the cultural, economic, educational (level of education), gender and social conditions experienced by those affected and their influence on the way in which they understand their pathology. The more positive the attitudes are developed before the complications are experienced, the greater the effectiveness of the treatment.

Some theories may help in this process of confrontation, such as that of Viktor Emil Frankl known as "Logo therapy" or "Psychotherapy of the Sense of Life". This theory suggests that every human being is able to withstand the most intense sufferings, such as knowing the diagnosis and making a commitment to health monitoring. In this way, the theory proposes to rekindle the meaning of life, being necessary for this is that the person involved confronts the situations presented. Each person is responsible for their freedom and the nurse must monitor the actions taken by the patient and his family in the face of the suffering caused by the disease. [24]

When assessing the knowledge of the user in the health services, we allow the horizontalisation of knowledge and the co-responsibility of the same in the face of its treatment. The user should be included in the context of his/her therapy as the main and active person, collaborating so that the assistance provided helps in adhering to the guidelines.

As a limitation of the study, the term "multidisciplinary" could have been misunderstood by those with less schooling. Therefore, specifying which professionals were associated with the multidisciplinary team on the form could have facilitated the analysis of this item.

\section{CONClusion}

Understanding the knowledge of people with diabetes is to identify what they have learned or accomplished regarding the actions of how they deal with pathology. This is the first step in facilitating appropriate changes to self-care.

All the patients' evaluated presented degrees of ignorance about DM. Hope in healing was still cited by a small proportion of them (4\%). It was recurrent citations of medicinal plants associated with drug therapy performed daily by the participants of the research. In this way, popular knowledge is part of the daily life of the diabetic patients investigated. Thus, the nurse must 
respect the individuality of the users at each consultation and likewise enable a moment of reception, qualified listening and creation of the affective-professional bond.

Knowledge of chronic complications was extracted, mainly in relation to visual changes such as blindness and complications of lower limbs such as amputations. There was a lack of knowledge regarding acute complications. The vast majority (70\%) of the patients knew how to take care of their feet; however, they did not use appropriate footwear.

Scientific knowledge sometimes disregards the empirical knowledge and the trajectory travelled by the user until the moment of the consultation. In this way, it becomes an important factor in the communication between the professional and the user, allowing a moment for the withdrawal of doubts and questions. Nonadherence or incorrect adherence to targeted therapy, directly affects the prognosis and evolution of the pathology.

\section{REFERENCES}

[1] Brasil. Ministério da Saúde. Secretaria de Vigilância em Saúde. Vigitel-Brasil 2011: vigilância de fatores de risco e proteção para doenças crônicas por inquérito. Brasília: Ministério da Saúde. 2017.

[2] Sociedade Brasileira de Diabetes. Diretrizes SBD 2015-2016. São Paulo: A.C. Farmacêutica.2016.

[3] Gross JL, Silveiro SP, Camargo JL, Reichelt AJ, Azevedo MJ. Diabetes Melito: Diagnóstico, Classificação e Avaliação do Controle Glicêmico. Arq. Bras. Endocrinol. Metab. 2002; 46:16-26.

[4] Tschiedel B. Complicações crônicas do diabetes. J. Bras. Med. 2014; 102:7-12.

[5] Ribeiro GSG. Custo do diabetes mellitus no sistema público de saúde brasileiro: Uma análise de políticas públicas de prevenção, educação e controle [monografia]. São Paulo (SP): Universidade de São Paulo. 2012.

[6] Borges TT, Rombaldi AJ, Knuth AG, Hallal PC. Conhecimento sobre fatores de risco para doenças crônicas: estudo de base populacional. Cad. Saúde. Pública. 2009; 25:1511-1520.

[7] Malta DC, Bernal RTI, Lima MG, de Araújo SSC, da Silva MMA, de Fátima Freitas MI, de Azevedo Barros MB. Doenças crônicas não transmissíveis e a utilização de serviços de saúde: análise da Pesquisa Nacional de Saúde no Brasil. Rev. Saude Publica. 2017; 51 Supl 1:4s 1-10.

[8] Antonio P. A psicologia e a doença crônica: Intervenção em grupo na Diabetes Mellitus. Psic. Saúde e Doença. 2010; 11:15-27.
[9] Flávia Fernanda Luchetti Rodrigues FFL, dos Santos MA, de Souza Teixeira CR, Gonela JT, Zanetti ML. Relação entre conhecimento, atitude, escolaridade e tempo de doença em indivíduos com diabetes mellitus. Acta. Paul. Enferm. 2012; 25:284-290.

[10] Brasil. Resolução n. 466, de 12 de dezembro de 2012. Dispõe sobre realização de pesquisa científica envolvendo seres humanos [internet]. Diário Oficial [da] República Federativa do Brasil, Brasília (DF), 13 Jun 2013. [citado em 2017 out 26]. Disponível em: <http:// conselho. saude.gov.br/resolucoes/ 2012/Reso46 6.pdf>.

[11] Mendes TAB, Goldbaum M, Segri NJ, Barros MBA. Diabetes mellitus: fatores associados à prevalência em idosos, medidas e práticas de controle e uso dos serviços de saúde em São Paulo, Brasil. Cadernos de Saúde Pública. Escola Nacional de Saúde Pública Sergio Arouca, Fundação Oswaldo Cruz, v. 27, n. 6, p. 1233-1243, 2011. Disponível em: <http://hdl. handle.net/11449/28770>

[12] De Menezes MC, Marçal PA, dos Santos LC, Souza LAC. Fatores associados ao diabetes Mellitus em participantes do Programa 'Academia da Cidade' na Região Leste do Município de Belo Horizonte, Minas Gerais, Brasil, 2007 e 2008. Epidemiol. Serv. Saúde [Internet]. 2011 Dez [cited 31 May 2018]; 20:439-448. Disponível em: http://scielo.iec. gov.br/scielo.php?script=sci_arttext\&pid=S167 9-49742011000 00003 \&lng=pt. http://dx.doi. org/10.5123/S1679-4974201100 0400003.

[13] Norris SL, Engelgau MM, Narayan KMV. Effectiveness of self-management training in Type 2 diabetes. Diabetes Care. 2001; 24:561587.

[14] Murphy HR, Rayman G, Skinner TC. Psychoeducational interventions for children and young people with Type 1 diabetes. Diabet. Med. 2006; 23:935-943.

[15] Leite SAO, Zanim LM, Granzotto PCD, Heupa $\mathrm{S}$, LamounierR RN. Pontos básicos de um programa de educação ao paciente com diabetes melito tipo 1. Arq. Bras. Endocrinol. Metab. [Internet] 2008; 52:233-242. [Cited on 24 Oct 2017]. Disponível em: http://www. scielo.br/pdf/abem/v52n2/10.pdf.

[16] Cardozo ACO, Martins CRAL. Correlação entre o envelhecimento e a hereditariedade no desenvolvimento de Diabetes Mellitus Tipo 2: um estudo transversal analítico. Rev. Divul. Cient. Sena Aires. 2012; 2:133-140.

[17] Cecílio AB, Resende LB, Costa AC, Cotta MM, Giacomini LF, Gomes LC, et al. Espécies vegetais indicadas no tratamento do diabetes. Rev. Eletr. Far. 2008; 5:23-27.

[18] Teles DIC. A Fitoterapia como tratamento complementar na Diabetes mellitus 
[dissertação]. Porto: Universidade Fernando Pessoa. 2013.

[19] Defani MA, Oliveira LEN. Utilização das plantas medicinais por diabéticos do município de Colorado (PR). Rev. Saúde e Pesq. 2015; 8:413-421.

[20] Mello RFA, Pires MLE, Kede J. Ficha de avaliação clínica de membros inferiores para prevenção do pé diabético. Revista cuidado é fundamental. J. Res.: Fundam. Care. Online 2017; 9:899-913.

[21] Dantas DV, Costa JL, Dantas RAN, Torres GV. Atuação do enfermeiro na prevenção do pé diabético e suas complicações: revisão de literatura. Carpe Diem: Rev. Cult e Cient do Unifacex. 2013; 11:1-14.

[22] Schulz RS, Moura BAP, Barreto ASML, Santana MS, Rabêlo JP. Ações educativas como estratégias de redução para pé diabético. Rev. Aten. Saúde. 2016; 14:79-84.

[23] Lima AB, De Oliveira DSR.Guia para o processo de ajuda interpessoal de enfermagem ao familiar does paciente crítico. Ciencia y Enfermeria XXIII (2), 2017.

Citation: Renata da Silva Schulz, Jéssica Ariadne Nascimento França, et.al, Knowledge of People Diagnosed with Diabetes Mellitus about their Pathology. ARC Journal of Diabetes and Endocrinology. 2019; 5(1):22-28. doi:dx.doi.org/10.20431/2455-5983.0501003.

Copyright: (c) 2019 Authors. This is an open-access article distributed under the terms of the Creative Commons Attribution License, which permits unrestricted use, distribution, and reproduction in any medium, provided the original author and source are credited. 